\title{
多孔性物質を設置した屈折流路内の伝熱流動に及ぼす グラスホフ数の影響
}

\section{Effect of Grashof Number on Heat Transfer and Flow in a Porous Medium Set in a Miter Bend Tube}

\author{
○機正 一宮 浩市 (山梨大工) $* 1$ 山岡 俊博 (丸誠重工 (株)） $* 2$
}

*1 Koichi ICHIMIYA, Yamanashi University, Takeda-4, Kofu, Yamanashi 400-8511

*2 Toshihiro YAMAOKA, Marusei Heavy Ind., Saiwai-2, Naniwaku, Osaka 556-0021

Key Words: Porous Medium, Miter Bend, Grashof Number, Laminar Flow, Numerical Calculation

本研究は、多孔性物質を多方面に使用するために、強制対 流場に自然対流を含んだ複合対流場を設定し、それを屈折流 路に適用した場合に、グラスホフ数が流路内の伝熱流動に与 える影響を数値的に評価したものである。

図 1 に座標系を示す。入口、出口高さ $\mathrm{y}_{0}$ の 2 次元平行平板 流路で幅 $2 \mathrm{y}_{0}$ の屈折部に多孔性物質を充填している。流路側 面 (Au-Ad), (Bu-Bd) から一様に加熱されている。流体は発 達した層流速度分布で流入し上部より下部へ流動し直線部 を経て流出する。

基礎式の内、多孔性物質内の流れに関玄式には Brinkman 項 (粘性項)、Forchheimer 項（慣性項）を考慮し た非ダルシーモデルに基づいている。外力として浮力項を考 慮した。エネルギー式では素材・流体間の熱伝達係数を考慮 した。

数优計算は基礎方程式を積分して保存形に表示して風上 差分を適用し反復法で行った。計算条件はレイノルズ数 $\mathrm{Re}=50$, 素材・流体間熱伝達パラメータ $\mathrm{H}_{\mathrm{a}}=100$, プラント 儿数 $\operatorname{Pr}=0.7$, 素材・流体熱伝導率比 $\lambda_{p} / \lambda_{a}=100$, グラスホ フ数 $\mathrm{Gr}=10^{2} \sim 10^{5}$, ダルシー数 $\mathrm{Da}=1 \sim 2.5 \times 10^{-6}$ で行った。
数值解析結果は $\mathrm{Gr}$ の影響を無次元流れ関数、流体及び素 材の無次元温度、側壁 (Au-Ad) および (Bu-Bd) 上の局所熱 伝達で評価した。 $\mathrm{Re}=50, \mathrm{Pr}=0.7, \mathrm{Da}=1.0$ において多孔性物質 が設置されないと流体は (Bu-Bd) に衝突し流動方向を変化 させると同時に側壁 (Au-Ad) 側の入口付近に時計回りの循 環流を生じる。多孔性物質を設置することにより速度分布が 一様化される傾向になり循環流領域吕狭くなる。 Gr の增大 と共に下流側に新たに浮力誘起の反時計回りの循環流が生 じる。(図 2)。上流側の循環流の中心は側壁 (Bu-Bd) 側へ移 行与る。

無次元流体温度は多孔性物質の挿入により温度上昇は高 く分布は一様化される。多孔性物質の素材の温度には $\mathrm{H}_{\mathrm{a}}=100$ に相当する流体との温度差が生じる。

側壁 (Au-Ad) 上の局所ヌセルト数 Nuは $\mathrm{Gr}$ の増大と共に 多孔性物質の入口、出口でわずかな減少はみられるものの大 きい変化はない。側壁 (Bu-Bd) 上では循環流に対応した流 れの加速のためNuは増大する。下流側になるにつれ減少し、 多孔性物質の出口付近では大小関係が逆転する。

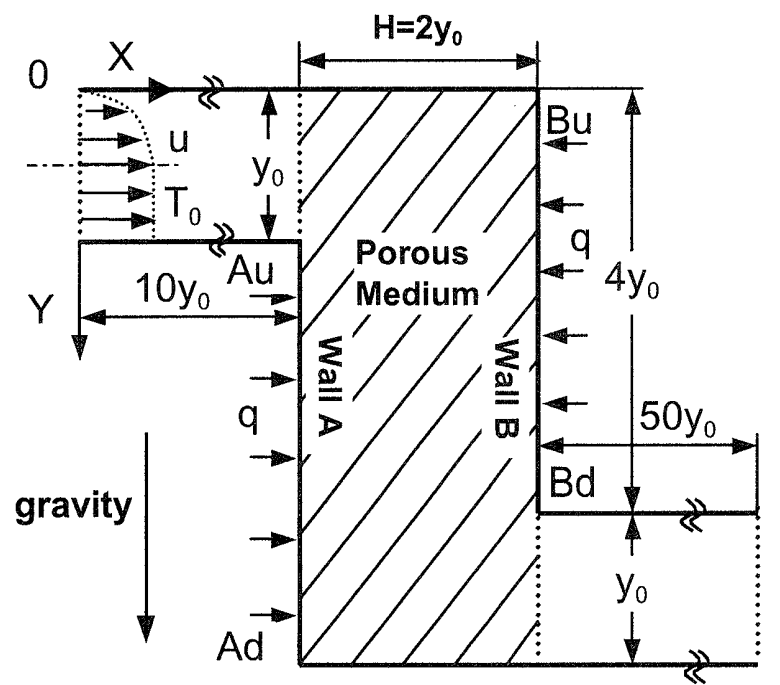

Fig. 1 Coordinate system

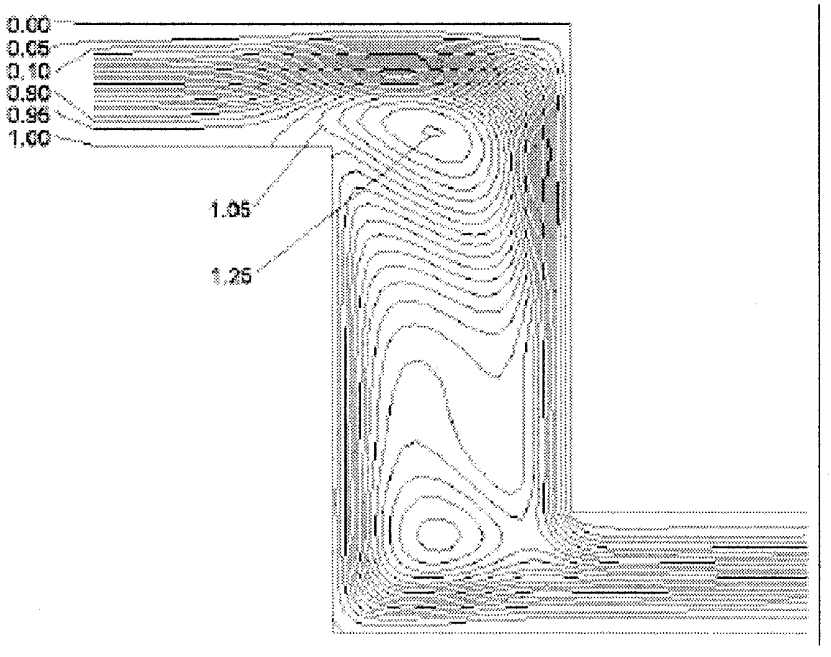

Fig.2 Dimensionless stream function $\left(\operatorname{Re}=50, \mathrm{Da}=1.0, \operatorname{Pr}=0.7, \mathrm{Gr}=10^{5}\right)$ 